40-1| 2015

Enjeux contemporains en études irlandaises - In Memoriam Paul Brennan

\title{
Patrick Cosgrove, Terence Dooley, and Karol Mullaney-Dignam (eds), Aspects of Irish Aristocratic Life: Essays on the Fitzgeralds and Carton House, Dublin
}

\section{Tim Mclnerney}

\section{(2) OpenEdition \\ Journals}

\section{Electronic version}

URL: http://journals.openedition.org/etudesirlandaises/4675

DOI: 10.4000/etudesirlandaises.4675

ISSN: 2259-8863

\section{Publisher}

Presses universitaires de Rennes

\section{Printed version}

Date of publication: 30 June 2015

Number of pages: $373-374$

ISBN: 978-2-7535-4082-8

ISSN: 0183-973X

\section{Electronic reference}

Tim McInerney, «Patrick Cosgrove, Terence Dooley, and Karol Mullaney-Dignam (eds), Aspects of Irish Aristocratic Life: Essays on the Fitzgeralds and Carton House, Dublin », Études irlandaises [Online], 40-1 | 2015, Online since 30 June 2015, connection on 19 April 2019. URL : http:// journals.openedition.org/etudesirlandaises/4675 


\title{
Patrick Cosgrove, Terence Dooley, and Karol Mullaney-Dignam (eds), Aspects of Irish Aristocratic Life: Essays on the Fitzgeralds and Carton House, Dublin
}

\author{
Tim Mclnerney
}

\section{REFERENCES}

Patrick Cosgrove, Terence Dooley, and Karol MullaneY-DignAm (eds), Aspects of Irish Aristocratic Life: Essays on the Fitzgeralds and Carton House, Dublin, UCD Press, 2014, , €50, ISBN 9781906359 713. www.ucdpress.ie.

1 The story of the Fitzgerald dynasty is, in many ways, the story of colonial Ireland: for almost 800 years, this family - whose spectacular estate at Maynooth stood literally and symbolically at the edge of Dublin's "Pale" - rose and fell with revolutions and reforms of their country. It is the Fitzgeralds' central role in Irish history that Aspects of Irish Aristocratic Life: Essays on the Fitzgeralds and Carton House aims to capture. While the preface to this collection of nineteen short essays claims not to provide an exhaustive history of the family, it nonetheless presents a remarkable reservoir of research, which will prove especially valuable to those seeking an introduction the Geraldine legacy. The volume is divided into three distinct sections, first reviewing the political rise of the Fitzgeralds in medieval and early-modern Ireland, then considering the architecture and social significance of their seat at Carton, before going on to examine some of the dynasty's most iconic figures, including James and Emily Fitzgerald, the $1^{\text {st }}$ Duke and Duchess of Leinster, and their notorious rebel son, Lord Edward Fitzgerald. 
2 Perhaps the most attractive aspect of this collection, however, is that while it covers a vast historical period, it also offers a strikingly intimate window into life at the Carton Demesne. Terence Dooley, for instance, analyses the particular rules and restrictions applied to the house's 50 or so servants - all scrupulously recorded by the $1^{\text {st }}$ Duke and Duchess in the estate's "household book". William Laffan, Brendan Rooney, and Alison Fitzgerald too, shine new light on Carton's collection of objects and paintings, detailing how they would originally have been presented, and where indeed they have ended up today. This sense of intimacy is not confined to domestic matters: the volume makes extensive use of surveys and draughts to trace the development of the ducal village of Maynooth and its Catholic seminary - an institution that has long stood as a monument to the Roman Church in Ireland. From Raymond Gillespie's history of manorial development in the area from the twelfth through to the sixteenth century, to Arnold Horner's review of the new 'model village' in the eighteenth century, this great family is considered in relation to the generations of tenants and townspeople that depended on them.

3 Above all, however, the essays by Thomas Nelson, Elizabeth Heggs, and Liam Chambers provide fresh insights into the great political figures connected to the house - some of them giants of Irish history, and others largely forgotten - not only considering their history, but the various historiographies that have been woven around them. In all, this delightful collection, with its 27 beautiful colour prints, is a pleasurable and informative read, which is sure to provide a valuable resource for both novices and those already acquainted with the illustrious Geraldine tradition.

\section{AUTHORS}

\section{TIM MCINERNEY}

Université Sorbonne Nouvelle - Paris 3 